\title{
How Land Titling Promotes Prosperity in Developing Countries
}

\author{
Ray Trewin
}

$\mathbf{M}$ ANY developing countries are facing rapidly increasing demands on their scarce resources, especially land. Such demands are imposing associated pressures on traditional or informal titles to land, and highlighting the need for stronger property rights. Land titling and registration, in conjunction with an appropriate legal, institutional and social environment, can help meet this demand.

Land is the main productive asset in many developing countries. Whereas property rights in land represent 40 per cent of family assets in the United States, in developing countries they represent around 70 per cent (de Soto, 1993). Land titing and registration helps secure property rights and could offer associated public benefits such as an apparatus for better planning as well as an essential basis for the development of an efficient land market. It could also provide to land holders, including poor land holders, greater private land security, investment collateral, potentially higher incomes and land values.

If the benefits of land titling and registration are potentially so great, why does a large amount of land in developing countries remain unregistered under formal title? For example, it has been estimated that only 20 per cent of Indonesia's, and a similar percentage of Peru's, land is registered under formal title (Grant, 1996; de Soto, 1993). Does land titling and registration add anything to workable informal arrangements? An economist would naturally seek to answer these questions by searching for failures in the land titling market. Are the private benefits of land titling and registration too small relative to the public benefits? Are the private costs, in both money and time, of registering a land title through current public monopolies too large relative to the private benefits obtained? Are the benefits, both public and private, of registering a land title well understood? Is land titling and registration effective in the absence of the legal, institutional and social environment needed to enforce the property rights encompassed in land titles (this is especially likely to be true of communal land, which is still widespread in many developing countries)? These issues need to be understood if the benefits of land titling and registration are to be captured and maximised.

Ray Trewin is a Fellow of the Economics Division in the Research School of Pacific and Asian Studies at The Australian National University. 


\section{What Is Land Titling?}

This note follows the standard practice of referring to land titling for the separate land titling and registration components of an overall system of land ownerhip. 'Land titling' denotes the legal recognition of ownership or of an interest in a parcel of land (International Federation of Surveyors, 1995). More precisely, land titling is concerned with the rights, restrictions and responsibilities associated with forms of ownership and use of a parcel of land, often geometrically described in the title It includes, as well as rights to the use of the land and its yields, rights to transfer, mortgage or leasing.

'Land registration' denotes the official recording of the title. This record can become the primary evidence of ownership. It is a more advanced system than having the title as the primary evidence of ownership, and requires greater investment; but it provides better security and reliability, and hence lower transaction costs, thus promoting a more efficient land market. An appropriate land regstration system is necessary if the full benefits of land titling are to be realised.

Many systems of land titling are in operation, reflecting the way boundaries are delimited and recorded; the Torrens system that is used in Australia is one erample. A country's optimal system of land titling depends on its resources, its social, political, legal and administrative environment, and so forth. Systems of land titling need not be uniform within countries, whether over time as the country develops or across all areas; for example, some indigenous groups within a country may wish to register as a community rather than as individuals.

\section{The Potential Benefits of Land Titling}

A framework for land titling and related projects is set out in the International Federation of Surveyors (1995) and the United Nations Interregional Meeting of Experts on the Cadastre (1996). This framework has underpinned many World Bank and other projects aimed at increasing the level of land titling. It predicts that introducing more efficient and transparent land transactions will result in less risky private land-related investment, greater overall investment through the use of more secure land as collateral, and incentives for longer-term investment towards more sustainable land use, leading to changes in input use, productivity, incomes, land prices, and so on.

Land titling has traditionally been undertaken by public utilities. Many of the more obvious benefits have been public ones: for example, a comprehensive register of land titles provides a basis for government land taxes as well as a potertially low-cost apparatus for assessing land resources and planning their appropriate use. Moreover, land titling provides an essential basis for an efficient land market vhere land is allocated to its potentially highest value use, including social values, through secure transfers of ownership or possession. Land titling also supplies indirect public benefits, including the incentive through the provision of stronger property rights for owners to take better care of their land. But it can have negative effects as well. For example, land titling could, if not properly implemented, exacerbate economic inequality, environmental stress and political instability. 


\section{Evidence of the Impact of Land Titling}

Much of the evidence that is emerging of the impacts of land titling is described in a recent paper by Feder and Nishio (1996).

Feder (1987) and Feder et al. (1988) show that farmers with legal title gained access to 52-521 per cent more institutional credit (depending on the province) than farmers without legal title, both because titled land was available as collateral and because it was 25-132.6 per cent more valuable than untitled land. Moreover, titled farmers invested more in land, and used more inputs and produced more output, than untitled farmers, resulting in 14.5-20.8 per cent higher revenues (agricultural and non-agricultural). As well, three to four years after the issuance of titles, titled land in project areas stimulated 35-205 per cent more land transactions than land in non-project areas (Onchan \& Aungsumalin, 1993).

Similar results have been observed in urban areas. Dowall and Leaf (1990) found, after taking into account the level of infrastructure and distance from the city centre, that residential land prices in Jakarta were strongly positively correlated with the degree of tenure security (as certified by registration and tax receipts).

More recently, evidence of the impact of land titling has been available from Latin America. Lopez (1996) shows that titled farmers in Honduras had greater access to credit, both in terms of numbers receiving credit and (more significantly) the average amount of credit received; they also invested more than twice as much as untitled farmers, especially in land-related investments. Moreover, with farms that were similar in 1983, titling led to significantly different yields by 1993. The rate of return from land titling was estimated at 17 per cent, which is significantly higher than the real lending rate in Honduras. Carter and Olinto (1996) find similar results for Paraguay farmers with land-related investment and credit provision. De Soto (1993) found that investment in property increased ninefold when squatters in Peru formalised their property titles. The IDB (1986) reported that land titling increased squatters' incomes by 200 per cent in Brazil and doubled farmers' incomes in Ecuador. The World Bank (1992) presents some of the broader impacts of land titling, such as reduced forest damage in Thailand, a tripling of household investment in sanitation facilities in Bandung, Indonesia, reduced soil erosion in Kenya, and improved land management in Burkina Faso.

\section{Overcoming Market Failure}

In view of the apparent net social benefits of land titling, why is the practice not more widespread? A key potential reason is institutional failure, primarily the $\mathrm{ab}$ sence of an appropriate legal, institutional and social framework to support the property rights encompassed in land titling. Another reason is the absence of net private benefits from land titling, which may result in the loss of potential net social benefits.

Different approaches to land titling and registration that address market failure have been developed. For example, in many developing countries, such as The Philippines, Thailand, Indonesia, and those in sub-Saharan Africa, the World Bank 
has been involved in 'systematic registration', which involves surveying and adjudicating all eligible parcels of land in a contiguous area during the one phase. It is intended as an improvement on traditional, sporadic registration practices in which individual landowners apply to register their parcels of land without the benefit of supporting processes such as comprehensive and integrated surveying. It has been estimated that at the current rate of sporadic registration it would take 90 years to register all current parcels in Indonesia; yet such parcels are growing at more than one million a year (Inside Indonesia, 1996).

Systematic registration addresses a number of market and other failures by extending the current legal framework through separate adjudications, cheaper processes, greater public awareness, as well as increased community and private sector involvement. A good example of the approach is the Indonesian Land Administration Project (ILAP), which builds on earlier projects in Thailand and the Philippines (see Grant, 1996), although the specific institutions, customs, and so foth are different. The ILAP is being undertaken by the government of Indonesi with World Bank funding and Australian technical assistance. It has three main objectives: to assist the national land agency in accelerating land titling and registration; to improve the institutional framework for sustainable land administration; and to help the Indonesian government develop sustainable land management policies. The first two objectives are designed to foster efficient and equitable land markets, and to alleviate conflict over land from development pressures. The third objective addresses longer-term inter-agency and cross-sectoral issues.

Privatisation has also been adopted to overcome market and other failures in land titling. In Peru, obtaining a title used to involve over 200 bureaucratic steps in nearly 50 government offices, and took, on average, over two and a half years to compete at the cost of a fifth of the official minimal annual wage. More recently, some South American countries have tried low-cost, decentralised privatisation based on a computerised register with important links to credit provision that specifically targeted the poor (The Economist, 9 December 1995). This last aspect could be particularly important in South America, where land holdings tend to be larger, and in the hands of wealthier owners, than in Asia.

A third approach is the 'evolutionary' one. Many so-called traditional systems have in reality evolved as a result of various social, economic and political pressures. In Africa, indigenous land rights have evolved away from a system of communal control towards individualised rights in response to increased commercial and population pressures (Migot-Adholla et al., 1991). Similar observations have been made in the Pacific (Crocombe, 1987). In fact, most of the titled land systems in the world's developed countries have evolved from communal land systems. Such systems survive in the form of strata titles with general boundaries and administrative arrangements for individual properties and common areas similar to those in some traditional communities. In fact, 20 per cent of Australian titles are of this form (Williamson, 1997). As agriculture intensifies as a result of increased commercialisation and population pressures, landholders themselves often demand stronger private land rights. Communal control often involves market failures such 
as 'free rider' problems and also high transaction costs in dealings with outsiders. Many of the informal institutions that have evolved within the communal land systems have been the result of attempts to reduce such transaction costs.

\section{The Impact on the Poor}

It has been argued that the poor are better off without land titling (Inside Indonesia, 1996). Allegedly, more information on land ownership disadvantages the poor both because it increases inequalities of access to information, and because, by encouraging development, it could result in the poor being thrown off their land. Lakau (1995) argues that traditional land ownership provides a kind of social safety net. However, governments could provide more information to potentially disadvantaged groups and also supply appropriate safety nets. As well, the poor are often disadvantaged by old land systems under which their land can be confiscated without compensation.

Cases have recently been reported of the poor in South America seizing unused land and other property. In fact, in many developing countries the landless poor often establish themselves on unused land ranging from abandoned railway yards to virgin forest lands. Such informal property rights could become a cause of future conflict; but land titling can legitimise them by recognising established occupancy and in this respect give priority to the poor.

A further way to help the poor is to legislate for covenants on land use, as already happens for environmental reasons. Other approaches include land committees and other organisations charged with overseeing the bona fides of land transactions. Such trade-offs between efficiency and equity could protect the rights of needy minorities without unduly constraining development opportunities.

\section{Conclusion}

Appropriate land titling, in conjunction with a relevant legal, institutional and social environment, can promote prosperity in developing countries by providing a more efficient land market with secure property rights, investment collateral, sustainable land use, income opportunities, and so on, as well as a good framework for public land use planning. It does this by addressing failures in current systems, including a paucity of information on the benefits of land titling and high transaction costs. There is a spectrum of land titling systems, both public and private, with the most appropriate system for a country depending on the available resources, and the specific legal, administrative, social and political environment, as well as how well the system addresses the failures. The poor have been badly disadvantaged by the pressures on current informal systems and can be targeted to benefit more within new systems that can make miscarriages of justice more transparent and any compensation fairer. 


\section{References}

Carter, M. \& P. Olinto (1996), 'Decomposition and Identification of the Impact of Land Titling on Agricultural Productivity in Paraguay', Department of Agricultural Economics, University of Wisconsin.

Crocombe, R. (1987), Land Tenure in the Pacific, Oxford University Press, Melbourne.

de Soto, H. (1993), 'The Missing Ingredient: What Poor Countries will Need to Make their Markets Work', in 'The Future Surveyed', The Economist, 11-17 September: 8-12.

Dowall, D. \& M. Leaf (1990), 'The Price of Land for Housing in Jakarta: An Analysis of the Effects of Location, Urban Infrastructure and Tenure in Residential Plot Prices', Department of City and Regional Planning, University of California, Berkeley (document prepared for USAID).

Feder, G. (1987), 'Land Registration and Titling from an Economist's Perspective: A Case Study in Rural Thailand', Survey Review 29(229): 163-74.

Feder, G., T. Onchan, Y. Chamlamwong \& C. Hongladarom (1988), Land Policies and Farm Productivity in Thailand, John Hopkins University Press, Baltimore.

Feder, G. \& A. Nishio (1996), 'The Benefits of Land Registration and Titling: Economic and Social Perspectives', paper presented at the International Conference of Land Tenure and Administration, Orlando, Florida (November 12-14).

Grant, C. (1996), 'Indonesia - the Other Land Titling Project', paper presented to the 37th Australian Surveyors Congress, Perth (13-19 April).

Inside Indonesia (1996), 'Introducing INFID: We Promote Community-based Land Mapping', JulySeptember: 26-7.

Inter-American Development Bank (IDB) (1986), Jamaica Land Titling Project: Feasibility Report, Washington DC.

International Federation of Surveyors (1995), 'Statement on the Cadastre', Publication No. 11.

Lakau, A. (1995), Customary Land Tenure, Customary Land Owners and the Proposals For Customary Land Reform in PNG, Pacific Land Tenure and Policy Centre, Lae.

Lopez, R. (1996), 'Land Titles and Farm Productivity in Honduras', Department of Agricultural and Resource Economics, University of Maryland.

Migot-Adholla, S., P. Hazell, B. Blarel \& F. Place (1991), 'Indigenous Land Rights Systems in SubSaharan Africa: A Constraint on Productivity?', The World Bank Economic Review 5(1): 155-75.

Onchan, T. \& S. Aungsumalin (1993), Final Report of Socio-Economic Evaluation of the Land Titling Project, Centre for Applied Economics, Kasetsart University, Bangkok.

United Nations Interregional Meeting of Experts on the Cadastre (1996), 'The Bogor Declaration', Bogor (18-22 March).

Williamson, I. (1997), 'The Justification of Cadastral Systems in Developing Countries', Geomatica 51(1): $21-36$.

World Bank (1992), World Development Report: Development and the Environment, Oxford University Press, New York. 